\title{
Importance of state regulation of the tourism industry In the Republic of Kazakhstan
}

\author{
Ludmila Lipkova ${ }^{1}$, Ainur Madiyarova ${ }^{2,}$, Aigerim Blembayeva ${ }^{2}$ \\ ${ }^{1}$ University of Economics in Bratislava, Dolnozemská cesta 1, 852 35, Bratislava, Slovakia \\ ${ }^{2}$ Al-Farabi Kazakh National University, 71, al Farabi ave., 050040 Almaty, Republic of Kazakhstan
}

\begin{abstract}
Tourism is a complex, highly profitable cross-industry complex and is one of the main sectors of the world economy. It is recognized as one of the most effective tools for supporting and stimulating the development of local, regional and national economies in many countries of the world. Often, tourism proved to be a lever in different countries, the use of which made it possible to improve the entire national economy of the country. In many countries, tourism plays a significant role in shaping the gross domestic product, creating additional jobs and employment, and activating the foreign trade balance. Tourism has a huge impact on such key sectors of the economy as transport and communications, construction, agriculture, production of consumer goods, and others, i.e. it acts as a kind of catalyst for social and economic development.

The experience of foreign countries shows that it is possible to achieve competitiveness in the world tourism market by developing new forms of economic integration between the state, tourism business and the country's population. Therefore, the formation and creation of favorable conditions for the effective functioning of tourist clusters is one of the priorities of the state tourism policy of Kazakhstan.
\end{abstract}

\section{Introduction}

Travel industry has a unique structure; it is characterized by the presence of a number of elements that include various branches of service: small restaurants, motels, hotels, holiday homes, laundries, shops, etc.

Thus, government investments in infrastructure, and sometimes in the expensive material and technical base of tourism, stimulate investment from numerous small businesses. Over time, the initial investment in tourism attracts even greater investments in auxiliary and supporting sectors of the economy: hotels, restaurants, shopping centers, ports, airports, etc [1].

Tourism can be good for development when it engenders a strong inflow of foreign exchange and positive inter-sectoral linkages which promote growth. [2]. But, tourism can also be bad for development if there is a negative inter-sectoral linkage (if developed at the

\footnotetext{
* Corresponding author: madiyarova.ainur@gmail.com
} 
expense of other sectors such as agriculture and manufacturing), strong leakage through high imports of food and beverages, and little value-added to GDP[3].

Now the most important tool for tourism development is information and communication technologies. E-tourism will enable stakeholders in the tourism sector all over the world to access information. This can increase sales and revenue in the local economy. The imbalance between competing destinations in global markets can also be found within tourism. Developing countries should be more active in understanding the implications of ICT development in the tourism industry. Policy makers should be involved in this process so that planning and implementation become more effective and strategic in nature. It is believed that development Strategies should now be an integral part of all policy planning, which also includes policy planning related to the tourism industry[4].

The main task of the state policy in the field of tourism is to implement the interests of the local population and all subjects of the tourism industry through mutual agreement. At the target level, policy interests are determined and implemented by government agencies in conjunction with other structures.

State regulation of tourism the aims of the government in the conceptual reflection of the role and place of tourism in human life and society and is based on public consent and is based on the definition of priority directions of tourism development, the regulation of inbound and outbound tourism, developing local and state programs, legal, financial, personnel and information security[5].

The main goal of state regulation is to create optimal conditions for the development of tourism through the use of legal and economic mechanisms, the distribution of material and human resources, taking into account their priorities.

The concept of state regulation is developed taking into account two factors:

a) provide for national interests that are determined by each state independently in accordance with the economic, political, social and other circumstances that take place in the country's economy, the political environment, tourism potential, the level of infrastructure development and the influence of other factors;;

b) international agreements, areas of international cooperation, regulatory and legal conditions that ensure the right of tourists to free movement, defining the tasks and role of the state in the development of domestic and international tourism, taking into account environmental, socio-cultural and safe conditions.

\section{Analysis of the tourism industry}

Tourism is not only the largest, but also the fastest growing sector of the world economy, whose growth rates are almost 2 times higher than the growth rates of other sectors of the economy. In terms of key indicators, including the efficiency of investment, tourism is comparable to the oil industry.

Tourism accounts for about $10 \%$ of the world's total product, $30 \%$ of global service exports, $7 \%$ of global investment, $10 \%$ of jobs, and $5 \%$ of all tax revenue.

On average, to generate income equivalent to that of a single foreign tourist, it is necessary to export to the world market about 9 tons of coal or 15 tons of oil, or 2 tons of high-grade wheat. At the same time, the sale of raw materials depletes the country's energy resources, and tourism works to renew resources. Each tourist entering the country spends on average about 20 US dollars every hour, 30 tourists generate 1 job.

Tourism, being an important segment of foreign trade that involves export-import operations with services, has the specifics of "invisible" exports. Unlike other sectors of the economy, whose products are transported to the consumer, it causes people to migrate to 
places where recreational resources are concentrated, and the consumption of these resources occurs in a certain place.

Currently, tourism is one of the most profitable businesses in the world. Using about $7 \%$ of the world's capital, tourism is firmly in third place after exports of oil, petroleum products and automobiles.

According to estimates of the UN world tourism organization, by 2030, it is expected that 1.8 billion people will travel to famous cities, popular resorts and monuments of history and culture, and revenues from hotel and tourist services will amount to approximately 2 trillion. in the tourism sector, 550 million jobs will be created.

Kazakhstan has developed a number of documents aimed at effective implementation of measures in the field of tourism, achieving the target indicators of its development. Among them are the State program for the development of the tourism industry of the Republic of Kazakhstan for 2019-2025 (approved by government decree No. 360 of may 31, 2019), as well as the Concept for the development of the tourism industry of the Republic of Kazakhstan until 2023 (approved by government decree No. 406 of June 30, 2017) [6].

Over the past 5 years, the share of tourism in gross value added averaged $1.1 \%$, showing its greatest growth in 2017, when the country hosted the international exhibition "EXPO", which was visited by more than 4 million people from 115 countries (table 1).

Table 1. Indicators of tourism development in 2014-2018.

\begin{tabular}{|l|l|l|l|l|l|}
\hline \multirow{2}{*}{ Indicators } & \multicolumn{4}{|c|}{ Years } \\
\cline { 2 - 6 } & 2014 & 2015 & 2016 & 2017 & 2018 \\
\hline $\begin{array}{l}\text { Share of gross value added, directly } \\
\text { in tourism, in gross domestic } \\
\text { product, percent }\end{array}$ & 0,8 & 1,0 & 1,2 & 1,3 & 1,6 \\
\hline Number of placements, units & 2056 & 2338 & 2754 & 2987 & 3322 \\
\hline $\begin{array}{l}\text { The list number of employees in the } \\
\text { tourism sector, including small } \\
\text { businesses engaged in } \\
\text { entrepreneurial activities (on } \\
\text { average for the reporting period), } \\
\text { thousand people }\end{array}$ & - & - & - & - & - \\
\hline - tourist firm & & & & & \\
\hline - placement & 6,5 & 7,3 & 7,2 & 7,3 & 7,4 \\
\hline - sanatorium institutions & 25,7 & 25,3 & 26,5 & 27,6 & 29,2 \\
\hline $\begin{array}{l}\text { Average monthly nominal accrued } \\
\text { salary of employees engaged in } \\
\text { tourism, including small businesses } \\
\text { engaged in entrepreneurial } \\
\text { activities, tenge }\end{array}$ & - & 10,3 & 10,0 & 9,6 & 8,0 \\
\hline - tourist firm & & & - & - & - \\
\hline $\begin{array}{l}\text { - placement } \\
\text { - sanatorium institutions }\end{array}$ & 71233 & 85002 & 94465 & 108152 & 95 \\
\hline $\begin{array}{l}\text { - source: the table is compiled according to the statistics Committee of the Ministry of national } \\
\text { economy of the Republic of Kazakhstan [7] }\end{array}$ & 86272 & 106823 & 112582 & 118606 & $\begin{array}{l}124 \\
217\end{array}$ \\
\hline & 76885 & 77245 & 83385 & 88163 & 90 \\
& & & & \\
\hline
\end{tabular}

The average increase in the number of placements in the Republic during the analyzed period was $12.8 \%$. The list number of employees in the tourism sector varies significantly depending on the object of work: for example, in 2018, it was 29.2 thousand people in places of 
accommodation, while the number of employees of travel agencies and health resorts for the same period was 7.4 and 8.0 thousand people, respectively.

The most important parameters of tourism development in the country are indicators of inbound and outbound tourism. Thus, in 2014-2018, the number of visitors for outbound tourism was about 52.4 million people, while for inbound tourism only-35.8 million people (table 2).

Table 2. Number of visitors for inbound and outbound tourism in 2014-2018, people.

\begin{tabular}{|l|l|l|l|l|l|}
\hline \multirow{2}{*}{ Indicators } & \multicolumn{5}{|c|}{ Years } \\
\cline { 2 - 6 } & 2014 & 2015 & 2016 & 2017 & 2018 \\
\hline $\begin{array}{l}\text { Number of visitors } \\
\text { for outbound tourism }\end{array}$ & 10449972 & 11302476 & 9755593 & 10260813 & 10646241 \\
\hline $\begin{array}{l}\text { Number of visitors } \\
\text { for inbound tourism }\end{array}$ & 6332734 & 6430158 & 6509390 & 7701196 & 8789314 \\
\hline $\begin{array}{l}\text { Source: the table is compiled according to the statistics Committee of the Ministry of national } \\
\text { economy of the Republic of Kazakhstan [7] }\end{array}$ \\
\hline
\end{tabular}

Today, both at the republican and regional levels, a lot of work is being done to attract foreign tourists to Kazakhstan; measures are being taken in the field of image policy and the popularization of tourist destinations of the country.

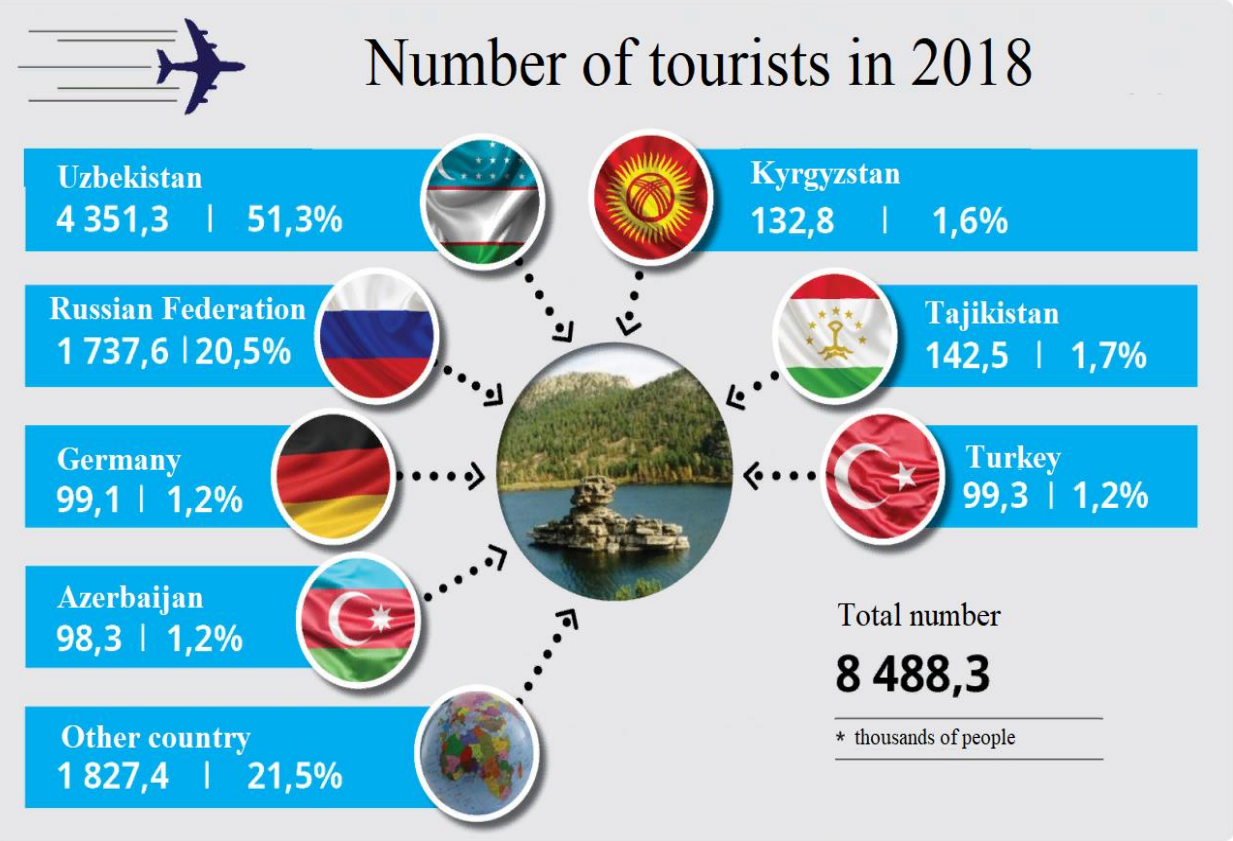

Source: Ministry of national economy of the Republic of Kazakhstan statistics Committee[8] Fig 1. Number of tourists in 2018.

According to the statistics Committee, in 2018, 8.5 million tourists visited Kazakhstan, this figure increased by $10 \%$ compared to 2017 . Also in $2018,75 \%$ of the 8.5 million "tourists" are citizens of neighboring countries with Kazakhstan: Uzbekistan, Russia, Kyrgyzstan and Tajikistan. The remaining 25\% are mainly residents of Turkey, Germany and Azerbaijan. 


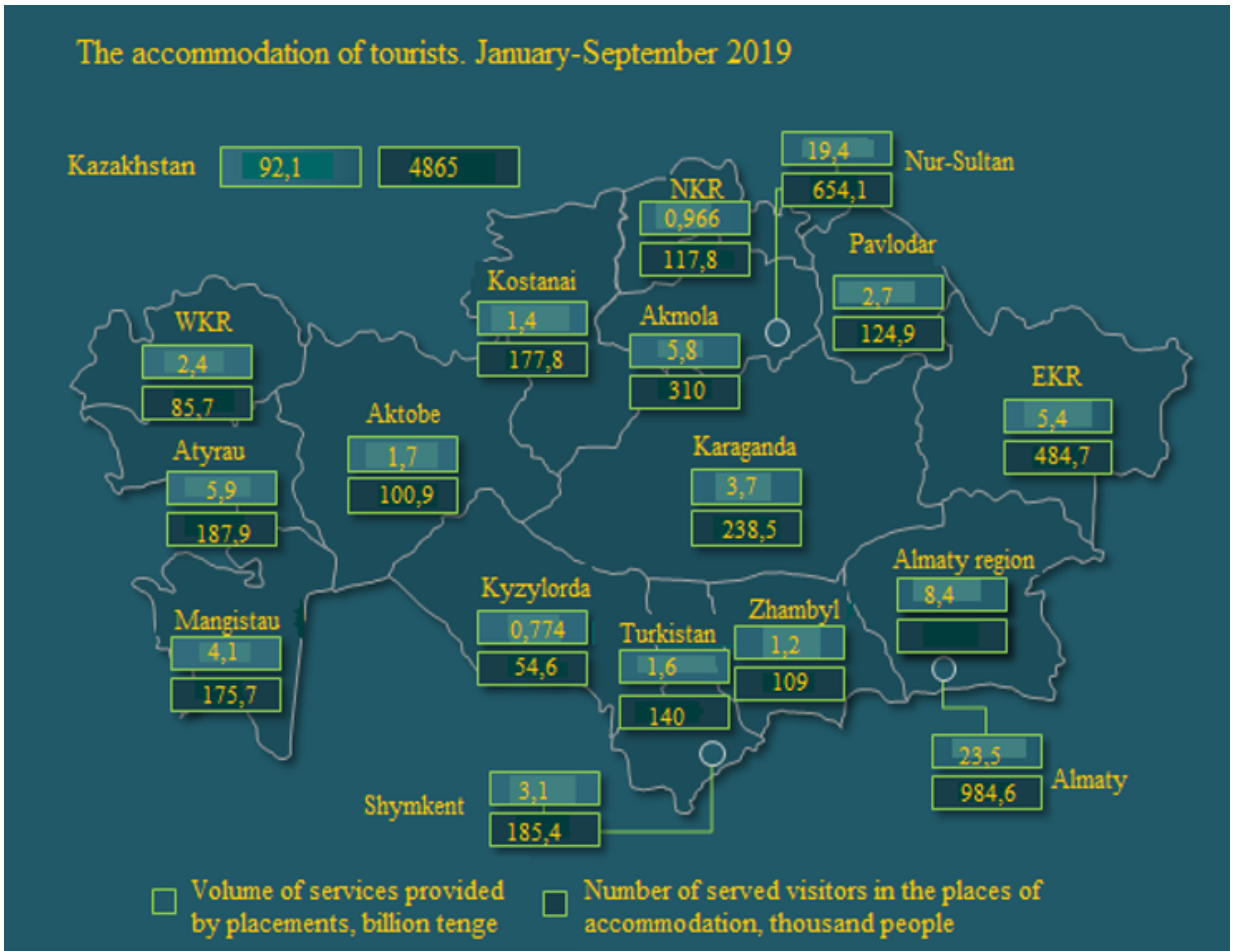

Source: Ministry of national economy of the Republic of Kazakhstan statistics Committee[8]

Fig 2. Tourist accommodation.

According to the results of January-September 2019, there is a decrease in the number of visitors to outbound and inbound tourism compared to the same period last year by $0.1 \%$, $5.4 \%$ and amounted to 8222.5 thousand people and 6440.6 thousand people, respectively. The number of visitors to domestic tourism increased by $9.8 \%$ compared to the same period last year and amounted to 5074.4 thousand people.

The number of guest accommodation units was 3,630, with 75,779 rooms, with a onetime capacity of 18,1153 beds. They served 4865.8 thousand people and provided services in the amount of 92077.6 million tenge. The volume of services provided by placements (excluding restaurant services) increased in the reporting period compared to the same period last year at comparable prices by $13.5 \%$

Table 3. Cost of services. February 2019 (tenge per day).

\begin{tabular}{|l|c|c|c|c|c|c|}
\hline & \multicolumn{2}{|c|}{2019} & \multicolumn{2}{c|}{2018} & \multicolumn{2}{c|}{ Growth for the year } \\
\cline { 2 - 7 } & $\begin{array}{l}\text { Hotel } \\
\text { accomm } \\
\text { odation }\end{array}$ & $\begin{array}{l}\text { Services } \\
\text { of } \\
\text { sanatori } \\
\text { ums }\end{array}$ & $\begin{array}{l}\text { Hotel } \\
\text { accommo } \\
\text { dation }\end{array}$ & $\begin{array}{l}\text { Services } \\
\text { of } \\
\text { sanatoriu } \\
\text { ms }\end{array}$ & $\begin{array}{l}\text { Hotel } \\
\text { accomm } \\
\text { odation }\end{array}$ & $\begin{array}{l}\text { Services of } \\
\text { sanatoriums }\end{array}$ \\
\hline Kazakhstan & 10283 & 9898 & 9345 & 9653 & $10,0 \%$ & $2,5 \%$ \\
\hline Nur-Sultan & 14908 & 14769 & 14908 & 13463 & - & $9,7 \%$ \\
\hline Almaty & 18624 & 12554 & 18245 & 11689 & $2,1 \%$ & $7.4 \%$ \\
\hline Kyzylorda & 7838 & 11323 & 7838 & 11039 & - & $2,6 \%$ \\
\hline Atyrau & 12264 & 11282 & 12264 & 11089 & - & $1,7 \%$ \\
\hline Kostanai & 7617 & 11039 & 7491 & 11285 & $1,7 \%$ & $-2,2 \%$ \\
\hline
\end{tabular}




\begin{tabular}{|l|c|c|c|c|c|c|}
\hline Pavlodar & 9251 & 10465 & 8279 & 9637 & $11,7 \%$ & $8,6 \%$ \\
\hline Oskemen & 9053 & 10390 & 9053 & 9881 & - & $5,2 \%$ \\
\hline Kokshetau & 8033 & 9622 & 7746 & 10581 & $3,7 \%$ & $-9,1 \%$ \\
\hline Semey & 8096 & 9489 & 6575 & 9635 & $23,1 \%$ & $-1,5 \%$ \\
\hline Petropavl & 11935 & 9392 & 10119 & 8858 & $17,9 \%$ & $6,0 \%$ \\
\hline Aktobe & 10194 & 9144 & 9496 & 8806 & $7,4 \%$ & $3,8 \%$ \\
\hline Karaganda & 8182 & 9031 & 6871 & 8909 & $19,1 \%$ & $1,4 \%$ \\
\hline Taraz & 11396 & 9007 & 11396 & 8580 & - & $5,0 \%$ \\
\hline Aktau & 10974 & 8853 & 10974 & 8853 & - & - \\
\hline Uralsk & 13054 & 8826 & 12123 & 8146 & $7,7 \%$ & $8,3 \%$ \\
\hline Shymkent & 10535 & 8713 & 10057 & 8241 & $4,8 \%$ & $5,7 \%$ \\
\hline Turkestan & 10466 & 8326 & - & - & - & - \\
\hline Taldykorgan & 8330 & 8092 & 5713 & 8092 & $45,8 \%$ & - \\
\hline Soure:
\end{tabular}

Source: Ministry of national economy of the Republic of Kazakhstan statistics Committee [8]

According to the results of February 2019, a day of hotel accommodation cost an average of 10,3 thousand tenge for Kazakhstanis and guests of the Republic of Kazakhstan - 10\% more than a year earlier. The highest prices among large cities and megacities are in Almaty $(18,6$ thousand tenge per day, $+2,1 \%$ year-on-year), Astana (14,9 thousand tenge) and Uralsk (13.1 thousand tenge, $+7,7 \%)$.

Sanatorium services cost an average of 9,9 thousand tenge per day, $+2,5 \%$ by February 2018. The highest prices were noted in Astana (14,7 thousand tenge per day, $+9,7 \%$ per year), Almaty (12,6 thousand tenge per day, $+7,4 \%$ year-to-year) and Kyzylorda (11,3 tg per day, $+2,6 \%)$.

\section{The importance of government regulation}

Tourism policy defines the main directions and creates conditions for the development of the tourism industry and other sectors of the economy focused on the tourist market. The essence of state regulation in the field of tourism is revealed by its goals, tools, mechanisms of processing and implementation. Any country that is interested in developing its tourism industry seeks to create conditions for sustainable development, i.e. to ensure that economic entities function effectively and that the flow of tourists, especially those engaged in domestic tourism, is not interrupted. This allows the state to get both economic benefits from the development of tourism (mainly as tax deductions to the budget) and social benefits (creating additional jobs, improving the population, preserving cultural attractions, etc.).

In this regard, the main tasks of the state in the field of state regulation of the tourism sector are:

- stimulating the development of a competitive tourist complex in the country;

- promotion and implementation of the use of international quality standards in the field of service for both domestic and foreign urists;

- maintaining the proportional development of economic sectors that are related to tourism in one way or another;

- creating conditions for the development of tourism infrastructure elements, etc.

In order to achieve the set goals, a number of measures are being taken in Kazakhstan, which can include:

- formation of the legal framework for the development of the tourism industry;

- creating favorable conditions for business development in the tourism sector;

- promotion of investment activities in the field of tourism business (especially domestic investments);

- improvement of mechanisms for licensing and certification of tourist services; 
- economic stimulation of the development of small and medium-sized businesses in the field of tourism through the provision of subsidies and concessionary loans.

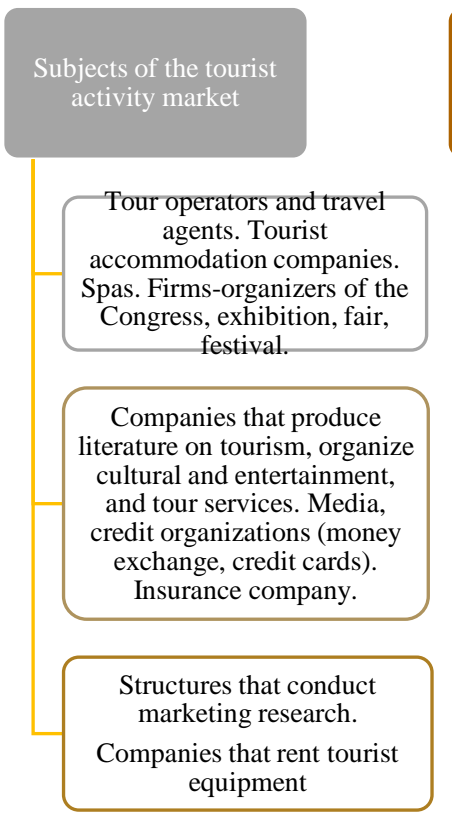

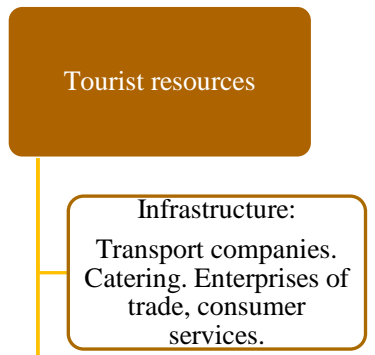

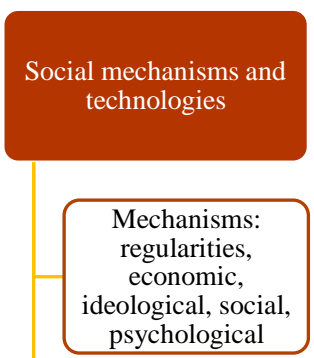

Pharmaceutical and light industry enterprises (sporting goods,

Souvenirs, clothing for tourism and recreation, and other goods of tourist demand)

Medical, cultural and educational
institutions (museums, etc.))
Tourist potential: landscape,
climate, political and cultural
premises

Fig 3. Elements of state regulation in the field of tourism.

In the Republic of Kazakhstan, the state regulates the tourism sector directly through the Committee of the tourism industry and through the national company "Kazakh Tourism" JSC, as well as indirectly — by using legal levers, by supporting its infrastructure, and within the framework of international policy.

Kazakh Tourism" National Company" JSC was established in 2017 following numerous successful events held in the country in order to continue promotion of Kazakhstan globally as a travel destination.

Kazakh Tourism, being the country's brand manager for tourism and a subsidiary of the Ministry of Culture and Sports, ensures comprehensive and holistic positioning of the country both internationally and domestically.

Kazakh Tourism places its focus on marketing and promotion of the country, attracting investments into tourism, and implementing of the National Tourism Development Strategy until 2025.

Kazakh tourism in its daily activities rely on partnership and alliances with international travel associations, development organizations, travel trade and media companies.

While serving the Government's goal to reach $8 \%$ input to GDP from tourism we believe in sustainable development through both economic and environmentally friendly growth based on strong communities and responsible business practices. 
Table 4. Functions and methods of state regulation of tourism development

\begin{tabular}{|c|c|}
\hline Functions & Methods \\
\hline $\begin{array}{l}\text { Ensuring the legal and regulatory } \\
\text { framework for the development of } \\
\text { tourism industry entities }\end{array}$ & $\begin{array}{l}\text { Development and adoption of legislative acts; approval of } \\
\text { rules for visa support for tourists and customs clearance of } \\
\text { imported (exported) goods }\end{array}$ \\
\hline $\begin{array}{l}\text { Development of short - term and } \\
\text { long-term plans for tourism } \\
\text { development }\end{array}$ & $\begin{array}{l}\text { Development and approval of state and regional } \\
\text { development programs, national strategies, etc. }\end{array}$ \\
\hline $\begin{array}{l}\text { Monitoring and promotion of } \\
\text { improving the quality of tourist } \\
\text { services provided }\end{array}$ & $\begin{array}{l}\text { Approval of the rules and procedure for licensing the } \\
\text { provision of tourist services; development and approval of } \\
\text { standards for tourist activities; certification of the provision } \\
\text { of tourist services }\end{array}$ \\
\hline $\begin{array}{l}\text { Development and implementation of } \\
\text { tools to ensure the safety of tourists }\end{array}$ & $\begin{array}{l}\text { Creating conditions for the development of insurance } \\
\text { institutions and increasing their responsibility to tourists in } \\
\text { the event of unforeseen circumstances; creating conditions } \\
\text { for medical support of tourists from the time of arrival to the } \\
\text { time of departure }\end{array}$ \\
\hline $\begin{array}{l}\text { Training of professional specialists } \\
\text { for the tourism sector }\end{array}$ & $\begin{array}{l}\text { Organization of training of specialists in higher educational } \\
\text { institutions of the country; creation of conditions for } \\
\text { improving the skills of workers in the tourism sector }\end{array}$ \\
\hline $\begin{array}{l}\text { Implementation of innovation policy } \\
\text { in the field of tourism }\end{array}$ & $\begin{array}{l}\text { Support for innovation in tourism through economic and } \\
\text { financial instruments; development of venture } \\
\text { entrepreneurship in the production of end products aimed at } \\
\text { meeting the needs of tourists }\end{array}$ \\
\hline $\begin{array}{l}\text { State support of tourist companies, } \\
\text { operating on international level }\end{array}$ & $\begin{array}{l}\text { Organization of tourist offices in foreign countries to assist } \\
\text { domestic travel companies in concluding contracts, } \\
\text { resolving conflicts, etc. }\end{array}$ \\
\hline $\begin{array}{l}\text { Monitoring compliance with the } \\
\text { principles of environmental policy } \\
\text { and preservation of the country's } \\
\text { cultural and historical heritage }\end{array}$ & $\begin{array}{l}\text { Stricter control over compliance with environmental policy } \\
\text { principles; state funding of activities aimed at preserving the } \\
\text { country's cultural and historical heritage (traditions, } \\
\text { monuments, museums, etc.) }\end{array}$ \\
\hline $\begin{array}{l}\text { Supporting the development of the } \\
\text { national tourism product and } \\
\text { preserving the country's tourist } \\
\text { image }\end{array}$ & $\begin{array}{l}\text { Active participation in international tourist exhibitions; } \\
\text { organization and holding of tourist exhibitions on the } \\
\text { territory of the Republic; attracting international companies } \\
\text { to develop commercials related to the national tourist } \\
\text { product, as well as scrolling them on the world's leading TV } \\
\text { channels; preferential taxation of tourist companies involved } \\
\text { in promoting the tourist image }\end{array}$ \\
\hline \multicolumn{2}{|c|}{$\begin{array}{l}\text { Source: A. Kh. Mukanov. The main directions of state regulation of the development of tourism in } \\
\text { Kazakhstan. Regional economics: theory and practice. } 27(258)-2012 \text { [9] }\end{array}$} \\
\hline
\end{tabular}

Recognizing tourism as one of the priority sectors of the economy, the country's leadership should ensure full interaction between the public and private sectors (figure 4).

In order to improve the efficiency of tourism development and involve business structures that have sufficient capital to implement tourism projects, it is necessary to develop more effective mechanisms of partnership between the state and business. Currently, Kazakhstan has attempted to implement a public-private partnership policy in the implementation of major projects. However, for a number of reasons, this policy did not cover all sectors of the economy, including tourism.

In order for the interaction of the state and business on the basis of partnership to have a long-term perspective, not be subject to corruption and monopolistic risks, and have the opportunity to develop in the tourism industry, it is necessary to develop the principles on which these relations of participants will be based. 


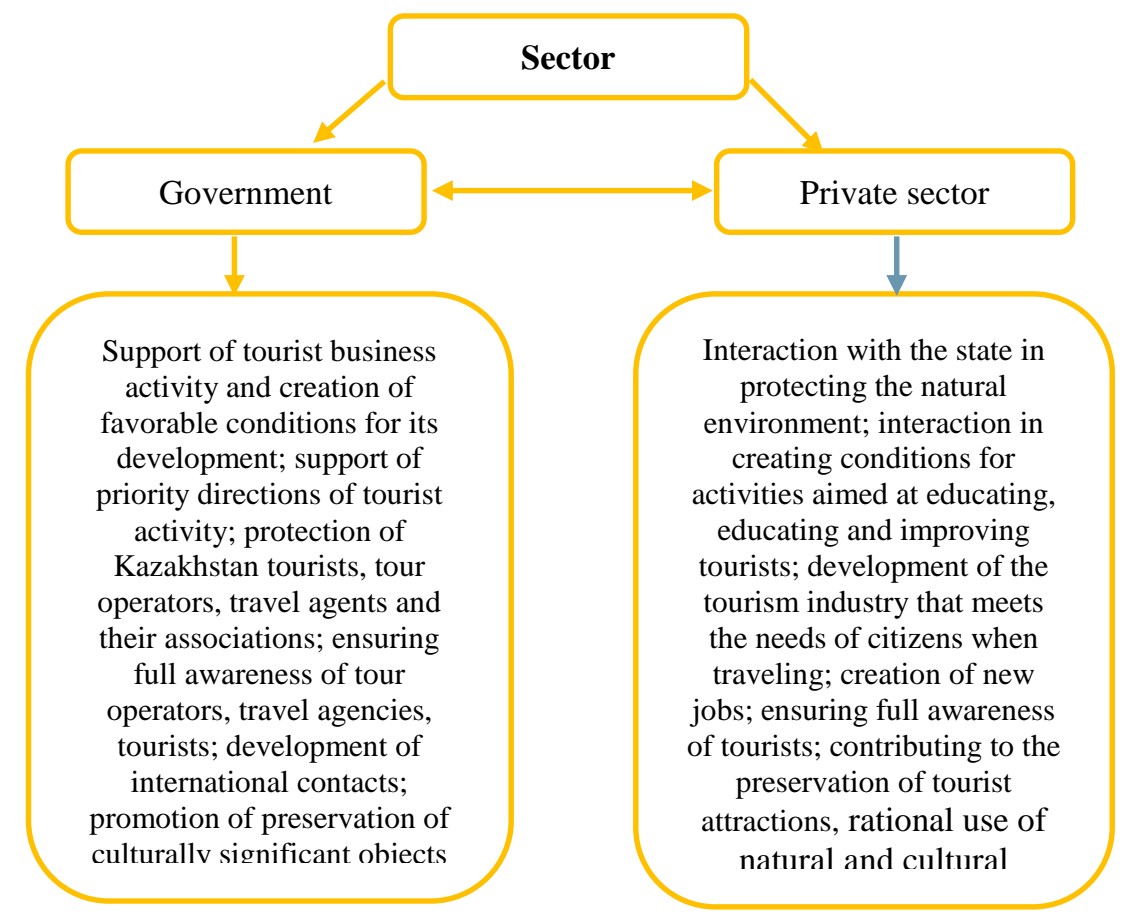

Fig 4. Interaction between the public and private sectors.

In most cases, business participation in partnership projects in the field of tourism is due to the latter's awareness of the possibilities of using state and municipal property, tourist resources that Kazakhstan has. Currently, such information exists in a fragmented form. As a rule, obtaining it involves going through a lot of conciliation and authorization administrative procedures, which complicates the access process and negatively affects the business initiatives of the private sector. These circumstances allow us to determine the principle of equal information provision to all stakeholders ' partnership (government, citizens and businesses) that provides a single information site "Kazakhstan tourism" to provide open access of all participants in the partnership to information on the market of tourist services.

The principle of step-by-step development of the tourism services market infrastructure on the basis of public-private partnership using state and municipal property involves the development of a methodology for the development of tourism infrastructure. At the same time, they are of particular importance:

- policy of increasing the tourist attractiveness of the region;

- policy of forming minimum standards for tourist infrastructure in the regions;

- policy of increasing cooperation of enterprises in the field of tourism business;

- mechanisms of public-private partnership in the tourist services market;

- policy of tourism business development in rural areas;

- policy of education and professional development of employees in the field of tourism business, growth of professionalism.

For the tourism sector, it is proposed to create a center for strategic development of the tourism industry in the form of a non-profit partnership that performs the following functions:

- managing the development of public-private partnerships in the tourism business;

- development of joint partnership projects with the state; 
- organization of project collection;

- conducting expert reviews of projects;

- conducting competitions among applicants for state support of projects. [9]

The processes of production, provision and consumption of services and products in the tourist services market need serious study by the state and detailed economic analysis to justify the correct key directions of development of this sphere.

\section{Conclusion}

The tourism industry around the world is a highly profitable economic activity. As world experience shows, in order to develop tourism, it is necessary to consolidate the efforts of all stakeholders in the tourism market, both in the private and public sector. On the other hand, the role of the Kazakh authorities is to improve infrastructure, as well as to plan and coordinate tourism development policies at the country and state level.

Of course, the development of tourism in the country faces a number of problems, including insufficient infrastructure development, low level of service in a number of regions, high prices for a number of services (especially for residents) [10], but, as already mentioned above, work is actively underway to solve them and create an attractive image of tourist destinations in the country. In this regard, we will consider some key trends in the development of tourism in Kazakhstan:

1. Holding of the UNWTO Global Summit on urban tourism. From 9 to 12 October 2019, Nur Sultan will host the VII Global summit on urban tourism. According to experts, it is expected that more than 700 people from 30 countries will visit it. The key theme of the summit is how the development of smart cities can help solve the problems of urban tourist destinations. It is also planned to discuss issues related to the sustainable development of cities, including tourism in the structure of smart-cities [11].

2. The introduction of the CityPass in other cities of Kazakhstan. In Kazakhstan, CityPass was developed For the development of tourism in cities such as Almaty, Nursultan and Burabay resort.

Summarizing analytical findings and trends of development, it is important to note that tourism of Kazakhstan for the last 5 years has undergone a significant change: each year, an increase in the number of non-resident visitors increased the share of tourism in GDP of the country has been a qualitative improvement of services related to the provision of placements, actively guided activities, for both internal and external tourists, applied significant effort to popularize tourist destinations of the country in social networks and on youtube. Crucial steps were the development and adoption of the State program of tourism industry development of the Republic of Kazakhstan until 2025 and the concept of tourism industry development until 2023, the effective implementation of which will undoubtedly contribute to the development of tourism business in the country, and, as a consequence, increasing the number of foreign guests.

3. The improved position in the ranking of Travel and Tourism Competitiveness Report 2019. In the 2019 ranking, Kazakhstan ranked 80th out of 140 countries, improving its position in comparison with the same rating in 2017. Among the CIS countries, Kazakhstan has the 3rd place (after Russia and Azerbaijan). Kazakhstan managed to get a higher expert rating on such criteria as" Price competitiveness"," Health and hygiene"," Business climate " [12].

4. Introduction of TAX FREE in Kazakhstan. From autumn 2019, foreign tourists will be able to receive tax refunds with the launch of the Tax free system on the territory of the Republic of Kazakhstan. This was made possible through negotiations with Global Blue, and will be implemented in a pilot mode for the time being. Tax refunds will only be possible if you purchase goods for an amount of at least $20 \mathrm{MCI}[13]$. 
5. Further development of the city of Turkestan as a center of international tourism and pilgrimage. The city of Turkestan is the historical and spiritual center of the Republic of Kazakhstan. During the first half of 2018, the city was visited by more than 720 thousand people. it is planned that the volume of tourist visits will soon reach about 1 million people. In the region, a plan for the development of the Azret-Sultan nature reserve has been developed for the development of ethnotourism; measures are envisaged to preserve the mausoleum of Khoja Ahmed Yassaui; and the creation of an administrative and business center[14].

6. Burabay is the best resort for summer holidays among the CIS countries in 2019. The analytical Agency Turstat in June 2019 compiled a rating of the best resorts in the CIS countries for summer holidays, where the first line was taken by the resort of Burabay. According to the experts of the statistical Agency, the following competitive advantages of the resort can be identified: visa-free entry, knowledge of the Russian language, relative low cost, hospitality of local residents, etc[15].

7. Development of urban tourism in cities and regions of the Republic of Kazakhstan. (information obtained from official Red Bus websites in cities of Kazakhstan). One of the main elements of excursion activities in the structure of urban tourism in many popular tourist destinations around the world is the popularization of double-Decker tourist buses that move along the route on the principle of "HOP ON, HOP OFF". Buses of this type have already appeared in Almaty, Nursultan e and Shymkent. The cost of an adult ticket in Almaty is 1500 tenge (about 4 us dollars), in Nursultan - 3000 tenge (about 8 us dollars), in Shymkent - 800 tenge (about 2 us dollars).

Summarizing analytical findings and trends of development, it is important to note that tourism of Kazakhstan for the last 5 years has undergone a significant change: each year, an increase in the number of non-resident visitors increased the share of tourism in GDP of the country has been a qualitative improvement of services related to the provision of placements, actively guided activities, for both internal and external tourists, applied significant effort to popularize tourist destinations of the country in social networks and on youtube. Crucial steps were the development and adoption of the State program of tourism industry development of the Republic of Kazakhstan until 2025 and the concept of tourism industry development until 2023, the effective implementation of which will undoubtedly contribute to the development of tourism business in the country, and, as a consequence, increasing the number of foreign guests.

\section{References}

1. Ziyadin, S., Madiyarova, A., Blembayeva, A. International tourism as a factor of world development. IBIMA 2018 - Vision 2020:( 2020)

2. Williams, M., The Political Economy of Tourism liberalization, Gender and the GATS, 2003

3. Mope, J., Ecotourism in the Less Developed Countries. Journal of Travel Research, Spring, pp. 41-55, 2004

4. Watkins, M., Ziyadin, S., Imatayeva, A., Kurmangalieva, A., \& Blembayeva, A. Digital tourism as a key factor in the development of the economy, DOI: 10.21003/ea.V169-08

5. Zh.N. Alieva "Fundamentals of Tourism" Almaty: Kazakh University, 2007

6. Gosudarstvennaya programma razvitiya turistskoy otrasli Respubliki Kazakhstan do 2025 goda: Postanovleniye Pravitel'stva Respubliki Kazakhstan ot 31 maya 2019 goda №360 // Informatsionnaya sistema «PARAGRAF». - 2019 
7. Turizm Kazakhstana: Statisticheskiy sbornik / Pod red. Aydapkelova N.S. - Astana: Komitet po statistike, 2019

8. Official website Ministry of national economy of the Republic of Kazakhstan statistics Committee - https://stat.gov.kz/official/industry/22/statistic/5

9. A. Kh. Mukanov. The main directions of state regulation of the development of tourism in Kazakhstan. Regional economics: theory and practice. 27 (258) - 2012

10. Ziyadin, S., \& Takhtaeva, R. Actual Problems of Economics,, (9), 232-236. (2014).

11. Global'nyy sammit po voprosam gorodskogo turizma proydet $\mathrm{v}$ stolitse [Elektronnyy resurs]. - Rezhim dostupa: https://bitly.su/0oP2xIb (accessed date: 19/02/2020)

12. Kazakhstan uluchshil pozitsii vo vsemirnom reytinge turizma [Elektronnyy resurs]. Rezhim dostupa: https://bitly.su/j9Zd (accessed date: 19/02/2020)

13. "Tax Free" in Kazakhstan. How will it be [Electronic resource]. - Access mode: https://bitly.su/U1X1 (accessed date: 19/02/2020)

14. Razvitiye turizma v Kazakhstane: Turkestan zhdet millionnogo turista [Elektronnyy resurs]. - Rezhim dostupa: https://bitly.su/175LRIZ (accessed date: 19/02/2020)

15. Burabay vozglavil reyting luchshikh kurortov v SNG dlya letnego otdykha [Elektronnyy resurs]. - Rezhim dostupa: https://bitly.su/KnYJ53o (accessed date: 19/02/2020)

16. Krotkova, E. V., Mullakhmetov, K. S., \& Akhmetshin, E. M.. Academy of Strategic Management Journal, 15(SpecialIssue1), 8-14. (2016). 